\title{
ST. ROBERT BELLARMINE, CONCILIARISM, AND THE LIMITS OF PAPAL POWER
}

\author{
CHRISTIAN D. WASHBURN*
}

The University of St. Thomas

\begin{abstract}
This article will examine Bellarmine's first anti-conciliarist work, found in the Disputationes de controversiis Christianae fidei adversus huius temporis haereticos, emphasizing his theological treatment of the pope's authority relative to the authority of a council and his repudiation of conciliarism. Bellarmine sees the conciliarists as attacking the divinely instituted Petrine structure of the Church. He does not advocate for an absolute papal monarchy in which there are no 'constitutional' limitations on the papacy. For Bellarmine, Christ and his Word, as found in Sacred Scripture and Apostolic Tradition, have supreme authority in the Church: one which the magisterium, whether papal or conciliar, must accept in humility and pass on unsullied. Only Christ has a true fullness of power; the pope has a fullness only relative to that of the bishops. Nevertheless, Christ immediately instituted the pope as the supreme head of the Church on earth, and as such, the pope has supreme ecclesiastical power over the whole Church on earth. Lastly, the article examines Bellarmine's position on papal heresy.
\end{abstract}

KEYWORDS: Bellarmine, Conciliarism, Infallibility, Papal Heresy, Magisterium

St. Robert Bellarmine (1542-1621) is perhaps the most important sixteenthcentury defender of the papacy. While there is a considerable body of research on Bellarmine's ecclesiology, there is but a small body of literature on his defense of papal supremacy in response to conciliarism. It has been suggested that Bellarmine was a papal absolutist who placed few limits on papal authority, while the conciliarists, in contrast, placed a series of 'constitutional' limits on papal power. This, however, is to deeply mischaracterize the debate, since all parties accepted constitutional limits on ecclesiastical power, whether papal or conciliar. The debate was really about whether supreme ecclesiastical power resided in the pope or in a council apart from the pope. This article will examine Bellarmine's first anti-conciliarist work, found in the Disputationes de controversiis Christianae fidei adversus huius temporis haereticos (hereafter cited as De Contoversiis), emphasizing that in his repudiation of conciliarism, Bellarmine did in fact acknowledge that there are 'constitutional' limits to a pope's authority. To this end, this article will give a short account of the of Dogmatic Theology, University of St. Thomas, St. Paul, MN. 
sixteenth-century context for Bellarmine's teaching on the relative authority of a pope to a council in the De controversiis. It will then examine Bellarmine's teaching that Christ is the only supreme head of the Church whose revelation has absolute authority for the Church. It will also treat of Bellarmine's doctrine that supreme ecclesiastical power resides in the papacy and that councils apart from the pope cannot exercise this power. Finally, this article will explain Bellarmine's views on the power of councils to depose a heretical or immoral pope.

\section{Background}

Conciliarism was initially proposed as a way to resolve the practical problem of multiple claimants to the papacy during the Western Schism (1378-1417); some theologians went on to construct a theology in which a council had real normative authority higher than that of the pope over both local churches and the universal Church. This conciliarism reached its zenith at the Council of Constance (1414-1418) in the decree Haec Sancta Synodus (1415), which asserted that a general council is higher than a pope (Mansi 1927: vol. 27, 590; Tanner 1990: vol. 1, 409). Conciliarism was rejected, however, by Pope Pius II and two ecumenical councils. Pius II condemned appealing to a council against a papal decision in the bull Exsecrabilis (18 January 1460) (Hünermann, Hoping, Fastiggi, Englund, and Denzinger 2012: 1375/717 [hereafter $\mathrm{DH}])$. Both the Council of Florence (1431-1443) and the 5th Lateran Council (1512-1517) also asserted a doctrine of papal supremacy (DH 1307/694; DH 1445/740; Morerod 2019: 271).

These magisterial interventions, however, did not end support for conciliarism and it continued well into the sixteenth century, not only at the University of Paris but also in Scotland, Germany, and even Rome (Oakley 1972: 452-453). It found able defenders in theologians such as Jacques Almain (c. 1480-1515) and John Mair (c. 1467-1550) (Oakley 1965: 673-90; Oakley 2003: 111- 140; Merzbacher 1967: 301-12). In the sixteenth century, Leo X and Clement VII considered conciliarism such a threat that it was one of the principal causes for the delay in calling the Council of Trent (Washburn 2019a: 631).

In the early sixteenth century, Luther too came to reject the superiority of a pope to a council. For a brief period in 1518 Luther had flirted with conciliarist views (Iserloh 1983: 563), but he quickly came to reject the authority of councils. Even so Luther appealed from the pope to a general council because he was convinced that the pope would soon condemn his heretical doctrines (Jedin 1957-1961: vol. 1, 172). At the diet held at Nuremberg in 1523, Luther called for a 'free, Christian council in a city on German soil' (Jedin 1957-1961: 1.211). Despite these calls, by 1520 Luther had moved well beyond the objections of fourteenth and fifteenth-century conciliarists 
concerning the structure of the Church and had repudiated almost every visible property that was constitutive of the Church's hierarchical and sacramental structure. These calls for a council were fundamentally disingenuous, as Pope Leo X noted in Exsurge Domine (1520), since Luther was calling for a council whose authority he no longer accepted (Leo X 1991: vol. 2, 396).

\section{Bellarmine and the Development of the De controversiis}

St. Robert Bellarmine joined the Jesuit order in 1560 and was ordained a priest in 1570. Not long after this, he began to teach scholastic theology at the Jesuit College in Louvain. While there, he began a systematic study of Catholic doctrine and doctrinal error. In 1570 Bellarmine requested and received permission to read heretical books, because at that time books written by heretics were kept in the Rector's room, and in August 1573 he was further allowed to read these in his own room (Bachelet 1911: 84-85; Ryan 1936: 57; Tromp 1933: 326-328). At this time, he began to compose his Compendium de haeresi, also known as the Index haereticorum. In this work, Bellarmine organized heresies by century, beginning with Thebutes in the first century and ending with Erasmus in the sixteenth century (Tromp 1934: 187-190). Although he cited from the works of both Juan de Torquemada, O.P. (13881468) and John Gerson (1363-1429) and identified some of Marsilius of Padua's (c. 1275-c. 1342) anti-papal theses as heretical, he did not deal explicitly with conciliarism (Bellarmine n.d. ms., Trier, Stadtbibliothek: 335 $336 \mathrm{r}^{\mathrm{r}}, 336^{\mathrm{v}}$ ). In 1570 he also began a series of lectures on Aquinas's Summa Theologiae that lasted for six years (Tromp 1935: 97-105; Bellarmine 15761577). While commenting on the Summa, he defended Thomistic and papalist ecclesiological positions such as a pope's superiority to a council and a council's inability to judge a pope (Horst 1978: 170-176; Löhr 1986: 149). Here Bellarmine often explicitly follows the positions of Thomist ecclesiologist such as Torquemada, Tommaso de Vio, O.P. (Cajetan, 1469-1534), and Francisco de Toledo, S.J. (1532-1596) (Löhr 1982: 662, 682, 713).

Upon falling ill in 1576, Bellarmine was sent to Rome to recover. Here he served as the professor of controversial theology at the Collegium Romanum, a position he held for eleven years, from 1576 to 1587 . The result of these lectures was his Disputationes de controversiis Christianae fidei adversus huius temporis haereticos, which he published in three volumes in 1586, 1588, and 1593 (Brodrick 1928: vol. 1, 132; Richardt 2004: 186, n. 4). Bellarmine divided the De Controversiis into fifteen controversies that roughly follow the outline of the creed (Bellarmine 1613: 1, sig. bij).

The fourth controversy, entitled De Ecclesia militante, tum in Conciliis congregata, tum sparsa toto orbe terrarium, is divided into four books (hereafter De ecclesia et conciliis). In the first two books of De Ecclesia militante, Bellarmine explains and defends the Church's doctrine on the nature and authority of 
councils. In book one, he discusses the different types of councils, the necessity of councils, and a pope's authority to convoke, to preside at, and to confirm a council of the Church. Bellarmine divided book two into two parts, examining different aspects of the authority of councils. The first half is devoted to explaining both the doctrinal and disciplinary authority of the various types of councils as well as conciliar infallibility (see Washburn 2010: 171192). The second half of book two, however, is devoted to explaining the authority of the pope relative to that of a council. Here at last he explicitly addresses the claims of conciliarists, proposing that supreme ecclesiastical power is proper to the papacy. The final two books of De ecclesia et conciliis deal with membership in the Church and the properties and notes of the Church of Christ.

Bellarmine's De ecclesia et conciliis is principally preoccupied with defending the spiritual authority of councils against Protestants, whom he cites 479 times (Richgels 1980: 9). When he comes to the question of the relative authority of councils to the pope, however, he only cites one Protestant, the Lutheran theologian Hermann Hamelmann (1526-1595). Bellarmine enumerates as his principal theological opponents fifteenth and sixteenth-century conciliarists: Pierre d'Ailly (Cameracensis, 1350-1425), John Gerson (1363-1429), Nicholas of Kues (1401-1464), Nicolò de' Tudeschi (Panormitanus, 1386-1445), Francesco Zabarella (Florentius, 1360-1417), Alonso Tostado (Tostatus Abulensis, c.1400-1455), and Jacques Almain (c. 14801515) (Bellarmine 1613: 4.2.14, vol. 1, col. 90; 4.1.2, vol. 2, col. 1). Years later, Bellarmine admitted in his controversy with Paolo Sarpi (1552-1623) that his efforts in book two of the fourth controversy were in part ordered to answering the arguments of Gerson and Almain (Bellarmine 1606: 29). It should be noted that Bellarmine does not refer to these theologians as 'conciliarists', although he occasionally refers to Gerson and Almain as 'Parisian theologians'.

Bellarmine cites as sources several opponents of Protestantism such as Albert Pigge (c. 1490-1542) and Nicholas Sanders (c. 1530-1581), but most of his sources are fifteenth and sixteenth-century anti-conciliarist theologians such as Domenico Jacobazzi (d. 1527) (Jacobazzi 1903; van Leeuwen 1533). Over half his sources are Thomist papalists: St. Thomas Aquinas (12251274), Petrus de Palude, O.P. (c.1275-1342), Torquemada, St. Antoninus, O.P. (1389-1459), Francesco Silvestri, O.P. (ca. 1474-1528), Cajetan, and Francisco Torres, S.J. (c. 1509-1584) (Palude 1966; Torquemada 1496; St. Antoninus 1959; Silvestri 1552; Cajetan 1936; Torres 1551).

\section{The Absolute Authority of Christ and His Word in the Church}

Sometimes the debate between conciliarists and papalists is presented as if it is about the absolute authority of either the pope or a council over the 
Church. For Bellarmine, however, neither the pope nor a council is ultimately the 'absolute' authority in the Church; only Christ is 'the supreme head and ruler of the whole Church' (summo capite et principe Ecclesiae totius) and the 'absolute and free king of the whole Church' (Regem absolutum, E liberum totius Ecclesiae) (Bellarmine 1613: 2.1.praefatio, vol. 1, col. 217; 3.1.5, vol. 1, col. 515). Bellarmine's use of the term free (liber) is striking; he uses it in an Aristotelian sense, meaning he who controls himself and is not under another (Deferrari 1960: 597-598).

In contrast, the pope is merely the vicar (vicarius) or steward (oeconomus) of Christ's kingdom on earth, and as a steward he is under the authority of another. Moreover, Bellarmine explicitly denies that the Church on earth is an 'absolute and free monarchy' (absoluta et libera Monarchia) (Bellarmine 1613: 3.1.5, vol. 1, col. 515). Costigan translates Bellarmine's phrase, 'absoluta et libera' as 'absolute and arbitrary', thereby interpreting Bellarmine to deny that there is an arbitrary monarchy in the Church. No doubt Bellarmine would deny this, but I think Bellarmine is making a different point (Costigan 2005: 23). Recall that Bellarmine has used the same language of 'absolute and free' for Christ, if this translation of 'liber' as arbitrary were correct, Bellarmine would be saying that Christ is an arbitrary king. Instead, Bellarmine is drawing a parallel between Christ's kingship and Peter's. Christ is an absolute and free king, i.e. not subject to another, whereas Peter and his successors are the stewards and servants of Christ. Moreover, Bellarmine also denies that the Church on earth is an 'absolute and free' monarchy, aristocracy, or democracy. In the end, whatever the Christian polity is to be, it is always one in subordination to Christ. To this end, Bellarmine cites 1 Corinthians 4:1: 'This is how one should regard us, as servants of Christ and stewards of the mysteries of God'.

In order to drive this point home, Bellarmine enumerates several ways that the pope's 'fullness of power' (plenitudinem potestatis) is inferior to Christ's fullness of power. First, Christ is the Head of the entire Church: the Church in heaven, in purgatory, and on earth; a pope only rules the Church on earth. Moreover, Christ's rule over the Church is eternal, while a pope's rule is only for the short time he is pope. Christ, as God, can promulgate divine law, establish sacraments, and bestow grace outside the sacraments. A pope cannot do any of these, nor can he change Christ's laws (Bellarmine 1613: 3.1.9, vol. 1, col. 535-536). If one compares Christ's authority to a pope's, one sees that a pope does not have the fullness of Christ's power but only the small portion which Christ has shared with him. Thus, when Catholics speak of a pope's fullness of power, this must be understood in a very limited way as referring to his teaching and jurisdictional authority on earth.

This is why Bellarmine typically speaks of a pope having 'supreme ecclesiastical power' rather than simply supreme power. The pope is said to have 
this 'fullness of power' not in relation to Christ but in relation to the power of bishops, who only have jurisdiction over their own dioceses (Bellarmine 1613: 3.1.9, vol. 1, col. 536).

The difference between Christ's divine authority and a pope's authority entails that there are also several fundamental differences between Christ's Word, as expressed in Sacred Scripture, and magisterial statements, whether papal or conciliar. First, the Sacred Scriptures are immediately revealed by God whereas magisterial decrees are not. The authors of Scripture were inspired by an immediate revelation that caused them to write the words of God Himself (Bellarmine 1613: 4.2.12, vol. 2, col. 86). Through this divine inspiration, God caused the sacred writers either to reveal that which was previously unknown or to write down the things which they had seen and heard. Second, God's inspiration so moved the sacred writers that they were not required to investigate the matter. Popes and councils, on the other hand, are morally obligated to study and to discuss thoroughly the subject matter prior to formulating their doctrinal decrees (Bellarmine 1613: 3.4.2, vol. 1, col. 794-795; 4.2.12, vol. 2, col. 87). Third, the Scriptures are inerrant in everything they assert, and Bellarmine labels as heretical the view that some parts of Scripture are of merely human origin and therefore capable of containing error (Bellarmine 1613: 1.1.4, vol. 1, col. 18). The only parts of magisterial decrees that necessarily do not contain error, on the other hand, are solemn definitions concerning faith and morals for the universal Church (Bellarmine 1613: 4.2.12, vol. 2, 87; see also Washburn 2010: 171-192). Other parts of magisterial statements can contain error. Moreover, for Bellarmine both popes and councils have on occasion taught factual or doctrinal error (Bellarmine 1613: 3.4.2, vol. 1, 793; 4.2.12, vol. 2, col. 87). Fourth, every word of Scripture requires the assent of faith, whereas only when the magisterium is defining something de fide is the assent of faith required (Bellarmine 1613: 1.1.15, vol. 1, col. 43). One can clearly see that God's revealed Word is superior to magisterial decrees in a number of important respects.

Some contemporary scholars give the distinct impression that the conflict over conciliarism was between the papal 'absolutists', like Bellarmine, who saw no limits on papal authority, and conciliarists (or later Gallicans), who held to a 'constitutional' view of the Church in which there are express limits on the pope's power (Costigan 2005: 22; Oakley 1996: 1-28; Oakley 1999: 65-86; Oakley 2003). This is a deep mischaracterization of the debate, as the forgoing analysis of Bellarmine's comparison of Christ's authority to that of the popes makes clear. Papalists like Cajetan, Cano, and Bellarmine thought that there are a number of distinct limits on the power of popes.

Both conciliarists and papalists held that Christ's headship and Peter's headship were not the same and that the pope's fullness of power is not the same as the fullness of Christ's power. The pope does not have absolute power 
in the Church simpliciter for two basic reasons: he is not God, and God has placed a series of constraints on him. If one insists on speaking of the relative authority of a pope to that of a council in terms of 'constitutional' limits, then it is better to characterize both papalists and conciliarists as having a 'constitutional' view of the Church. What is really at stake in the debate is which person or group within the Church receives supreme ecclesiastical power from the Church's constitution.

\section{The Supreme Pontiff is Head of the Church on Earth}

Some extreme conciliarists like Marsilius of Padua held a doctrine similar to Luther's, which simply denied Peter and his successors' headship over the Church (Bellarmine n.d. ms., Trier, Stadtbibliothek: 336 ${ }^{\mathrm{r}}$ ). More moderate conciliarists like Gerson and Almain, however, affirmed that Christ made Peter the head of the Church (Gerson 1966: 6.227-28; Almain 1728: cap. 8). Gerson was firmly convinced that the monarchical structure of the Church was part of its divine constitution (Posthumus Meyjes 1999: 169). These conciliarists accepted traditional catholic doctrine but raised questions about the nature and extent of that headship. Almain, for example, argued that the pope was the head of the Church in the sense that he had jurisdiction over every individual Christian of whatever rank, whether archbishop, bishop, priest or layman, but that the pope did not have jurisdiction over the whole Church either dispersed throughout the world or when it is gathered together in a council (Almain 1728: 2, col. 997).

Bellarmine holds that it is a 'pernicious heresy' to deny that the primacy of Peter was established by Christ (Bellarmine 1613: 3.1.10, vol. 1, col. 539). It is also of divine law that the Roman pontiff succeeds Peter in the primacy over the whole Church (Bellarmine 1613: 3.2.12, vol. 1, col. 626). Bellarmine is clear that the pope's headship extends to the whole Church and not just to its individual parts:

The Roman Pontiff has been constituted immediately by Christ not only as the pastor and head of all particular Churches, but also of the whole universal Church gathered together (Bellarmine 1613: 4.2.15, vol. 2, col. 92).

Bellarmine's argument for this thesis is primarily scriptural and largely based on two texts, Matthew 16:18-19 and John 21:17, both of which are common in the papalist literature preceding him (Cajetan 1936: cap. 1, p. 16; Jacobazzi 1903: vol. 0, pp. 243-244). He begins by expounding on the locus classicus asserting Petrine supremacy: 'You are Peter and upon this rock I will build my Church' (Matthew 16:18) (Bellarmine 1613: 3.1.10-13, vol. 1, cols. 539_ 559). Bellarmine's purpose with this text is to demonstrate two things. First, Peter is the foundation of the Church, and therefore the Church is fundamentally dependent upon him, just as a house is fundamentally dependent 
on its foundation. When Christ made Peter the foundation on which the Church is built, Christ wished to show the superiority of Peter to all other members of the Church (Bellarmine 1613: 4.2.15, vol. 2, col. 92). Second, when Christ said that He would build 'my Church', He made Peter the foundation of all the faithful and not only of some portion of the Church such as the church in Rome or some other local church, or of particular individuals, as a number of protestants and conciliarists had alleged (Bellarmine 1613: 4.2.15, vol. 2, col. 92).

Bellarmine then takes up the second locus classicus for asserting Petrine headship over a council: John 21. Bellarmine argues that when Christ said to Peter, 'Feed my sheep' (John 21:17), He intended to do two things. First, Christ was making Peter the chief pastor. Sheep, as Bellarmine notes, are completely dependent on their pastor, just as a house is on its foundation; and so the Church, whether scattered throughout the world or assembled together in a council, is dependent on Peter. Bellarmine concludes that Peter (and the successor of Peter), therefore, is the pastor of any gathering, even of general councils (Bellarmine 1613: 3.1.16, vol. 1, 562-564; 3.2.12, vol. 1, 627). Bellarmine's point is that these images of the relationship of a house to its foundation and of sheep to their pastor are images of complete dependency. Second, Bellarmine notes that Christ's sheep were given to Peter without distinction, and so Christ gave Peter authority over the whole flock and not just a portion of the flock (Bellarmine 1613: 4.2.15, vol. 2, col. 92). There is only one sheepfold of Christ, and so Christ entrusted the whole flock to Peter (Bellarmine 1613: 3.1.16, vol. 1, col. 563).

The Scriptures also repeatedly describe the Church as Christ's body. A body must have a head, and (monstrosity aside) it can have only one head. Therefore, the following conclusion could be made: just as a body completely depends upon its head, the body of Christ completely depends on Peter, its head (Bellarmine 1613: 4.2.15, vol. 2, col. 92).

\section{Supreme Ecclesiastical Power Is Not in a Council}

Some conciliarists had argued that supreme ecclesiastical power is not found principally in the pope; rather Christ bestowed it immediately upon both Peter and the Church (Almain 1728: cap. 6). Accordingly, councils do not have their authority from the pope but immediately from Christ. When general councils are assembled, supreme power is greater in a council than it is in a pope. Since the Church cannot always remain gathered in a council and exercise this supreme power ministerially or instrumentally, the pope will exercise this authority until a council is gathered. Once a council assembles, however, supreme ecclesiastical authority is more properly in a council than in a pope, whether or not the pope is part of the council. The pope is therefore subject to that power (Almain 1728: cap. 7, col. 998). 
Bellarmine rejects such a position, asserting:

Supreme ecclesiastical power, apart from the Pope, is neither formally (formaliter) nor suppletively (suppletive) in the Church or a council (Bellarmine 1613: 4.2.16, vol. 2, col. 93).

When Bellarmine says that neither the Church nor a council 'formally' has supreme ecclesiastical power, he means that they do not possess it by right. When he says that neither the Church nor a council 'suppletively' has supreme ecclesiastical power, he means that apart from the pope, no one can supply this authority to the Church or a council.

To defend this assertion Bellarmine argues two points. First, the Scriptures everywhere describe the Church as a kingdom with Christ as its king. To this end Bellarmine cites Psalm 2:6, which reads, 'But I am appointed king by him over Sion, his holy mountain, preaching his commandment', interpreting it to mean that God the Father appointed Christ as king of Sion, i.e., the Church, and that 'his kingdom will have no end' (Luke 1:33) (Bellarmine 1613: 4.2.16, vol. 2, col. 93, and 3.1.5, vol. 1, col. 515). Christ himself affirmed His kingship in His dialogue with Pilate. When Pilate asked Him, 'Are you the King of the Jews?' (John 18:36), Christ did not answer, 'I am not the King', or, 'My kingdom is not in this world', but rather He said, 'My kingship is not of this world'. Bellarmine uses this dialogue to demonstrate first, that Christ acknowledged His kingship and second, that Christ's kingship is not merely over a temporal kingdom like Herod's or the emperor's. The Scriptures also frequently refer to the Church as a kingdom (Bellarmine 1613: 4.2.16, vol. 2, col. 94; see Manelis 1940: 5-108), and of course only Christ can be the king or monarch of this kingdom. Secondly, Bellarmine argues that Christ's kingship is grounded in the hypostatic union. Christ as God is the lord and king of all creation on account of His divine nature, and Christ as man has received the power to rule all things on account of the hypostatic union. Christ governs the universe and all that is contained in it, including the Church, as a king (Bellarmine 1613: 4.2.16, vol. 2, col. 94). Thus, for Bellarmine, the Church is not merely a natural kingdom with a natural head but a supernatural kingdom with God as its head (Bellarmine 1613: 3.1.17, vol. 1, col. 522).

The Church has no authority but what Christ has given it, and the Scriptures are clear that Christ did not give supreme ecclesiastical authority to the Church apart from Peter; instead He immediately bestowed on Peter 'the keys of the kingdom of heaven' (Bellarmine 1613: 4.2.15, vol. 2, col. 92). It is in this metaphor of the keys of the kingdom that the pope's supremacy over the universal Church is contained. By examining the metaphor of the keys, Bellarmine explains that handing over the keys of a city to someone shows that the person is entitled to govern the same city and that he is able to admit 
or expel whomever he wants. Christ directly and immediately bestowed on Peter the supreme authority to govern the Church, but He did not give this authority to the entire body of the Church. Therefore, ecclesiastical councils which represent the universal Church do not and cannot have supreme authority in the Church unless, of course, they include Peter, in whom that gift is operative within them as a body united with him.

Bellarmine further argues that if supreme ecclesiastical power were principally in the Church, and only ministerally in the pope, then it would follow that the pope is not the immediate vicar of Christ. Instead, a pope would be mediately the vicar of Christ, and the Church would be the immediate vicar of Christ. This view, in Bellarmine's opinion, directly contradicts the decree of the Council of Constance which condemned Wyclif's teaching that the pope is not the immediate vicar of Christ (Bellarmine 1613: 4.2.15, vol. 2, col. 93; Tanner 1990: 1.413).

\section{The Supreme Pontiff Is Absolutely above a Council}

Bellarmine follows the position of other Thomists, such as Cajetan and Torquemada (Cajetan 1936: cap. 7, pp. 48-49; Torquemada 1496: lib. 3, cap. 24, p. $300^{\text {r }}$; lib. 3 cap. 44 , pp. $\left.324^{\mathrm{r}}-325^{\mathrm{r}}\right)$, that

the Supreme Pontiff is simply and absolutely above both the universal Church and a general council, so that he recognizes no judgment on earth above himself (Bellarmine 1613: 4.2.17, vol. 2, col. 99).

Bellarmine considers this a doctrine revealed in Sacred Scripture and therefore de fide. He uses the titles that Scripture attributes to Peter to draw this conclusion. First Bellarmine notes that Peter's special position is to be the steward (oeconomus) of the Church, just as Christ is the master of his household, the Church. Bellarmine refers to Christ's description of the steward's role: 'Who in your opinion is that faithful, farsighted steward whom the master will set over his servants to dispense their ration of grain in season?' (Luke 12:42). Thus, the steward is set over the master's servants, the master being Christ. The Fathers of the Church understood the steward to be the bishop, as head of the local church. Bellarmine then argues that just as the bishop is the steward of the local church, so too the Roman bishop is the steward of the universal Church (Bellarmine 1613: 4.2.17, vol. 2, col. 95). In Christ's analogy, it is only the master and not the family or other servants who can punish the steward (Luke 12:46), and so Bellarmine reasons it is only Christ, not a council, who can judge or punish the pope (Bellarmine 1613: 4.2.17, vol. 2, col. 96).

Bellarmine presses his point by assigning to the pope three other Christological titles of shepherd, head, and husband. Christ refers to Himself as the shepherd over His flock, the Church, in the Good Shepherd discourse: 'I 
am the good Shepherd' (John 10:14). Christ shares this role with Peter when He commands him to 'Feed my sheep' (John 21:16) (Bellarmine 1613: 4.2.17, vol. 2, col. 96). It is clear that a shepherd cannot be judged by his sheep; so, too, a pope cannot be judged by a council. Bellarmine also notes that the Scriptures liken Christ to the head of a body, a title that the Council of Chalcedon gave to Pope Leo the Great (Bellarmine 1613: 4.2.17, vol. 2, col. 96). Clearly, the head cannot be ruled by the members nor can the members cut off the head. So, too, the pope cannot be ruled or judged by a council. Lastly, Christ is compared to a spouse, as St. Paul in his letter to the Ephesians counsels husbands to 'love your wives as Christ loved the Church and gave himself up for her' (Ephesians 5:25). Again, Bellarmine points to the Second Council of Lyons (1274), which referred to the pope as the husband of the Church. He concludes that just as it is contrary to the order of nature and to Scripture that the wife is able to judge the husband, so too a council cannot judge the pope (Bellarmine 1613: 4.2.17, vol. 2, col. 96; Tanner 1990: vol. 1, p. 3175).

\section{Whether a Council Can Depose a Heretical or Immoral Pope}

Many conciliarists saw as their strongest argument the commonly held teaching that a pope could be judged if he fell into heresy. Conciliarists turned to a canon known by its incipit, Si Papa, which is included in Gratian's collection of Church law called Concordia discordantium canonum (c. 1140), a kind of medieval 'Denzinger' containing a collection of authoritative texts (Congar 1974: 90). Si Papa suggested that the first see cannot be judged 'except when he is convicted of deviation from the faith' (nisi deprehendatur a fide deuius) (Gratian 1955: vol. 1,146). From this exception conciliarists generally concluded two things. First, the pope can fall into heresy, a position held by all canonists (Moynihan 1961: 141-142; Tierney 2010: 9) and theologians in the Middle Ages, including papalists (Natalis 1966: 365; de Palude 1966: 196; Terreni 1926: 28, 30; Torquemada 1496: 1. 2, c. 102; Antoninus 1959: 3, cols. 1207-1208; Washburn 2019b: 550-552). Second, Si Papa entails that the pope can be judged for this heresy. Conciliarists argued that the appropriate means for judging the pope is a council since popes in the past were, in fact, judged by councils. Conciliarists concluded that if a council can judge a pope, then a council must have supreme ecclesiastical power.

Bellarmine's solution is to deny that the pope can be a formal heretic either in solemnly defining a matter of faith and morals for the universal Church or in teaching in other capacities such as a theologian (doctor privatus). This later position he qualifies with the theological note of 'probable and pious' (Bellarmine 1613: 3.4.6, vol. 1, 805; 3.2.30, vol. 1, 691). Such a view, of course, renders moot the question of whether a council can judge a pope, since such an event would not occur. This position that the pope will not fall into formal heresy even as a theologian was a sixteenth-century theological 
novelty popularized by the Dutch theologian Albert Pigge (c. 1490-1542) (Jedin 1931: 136). Bellarmine's position, however, is often misunderstood as entailing that the pope can never teach or hold doctrinal error or heresy. This is incorrect. First, Bellarmine divides all papal teaching into two categories: infallible solemn definitions and everything else. The pope is only infallible in hisi solemn definitions, everything else is fallible. Second, Bellarmine freely acknowledges both that the pope qua pontiff can err on factual questions (Bellarmine 1613: 3.4.2, vol. 1, 793) and that the pope as a private teacher (doctor privatus) can err through 'ignorance even in matters of faith and morals', just like any other human teacher (Bellarmine 1613: 3.4.2, vol. 1, 793). So, he clearly thinks that popes can and do make serious doctrinal errors. His position is not that the pope as a private teacher cannot be a heretic in any sense but only that the pope as a private teacher cannot be a heretic by 'pertinaciously' (pertinaciter) believing something contrary to the faith (Bellarmine 1613: 3.4.6, vol. 1, 805). His point, to use modern terminology, is that the pope as a private teacher can be a material heretic, but he will not be a formal heretic.

It is also important to note what Bellarmine means by 'judge'. He does not mean that an individual cannot render a judgment about whether the pope has or has not committed an act of heresy. What he means is that there is no one in the Church who can make a judicial or canonical judgment that could compel the pope to do something, since this would entail that there is a supreme ecclesiastical power in the Church greater than the pope.

Despite his position that it is pious to hold that the pope cannot become a pertinacious heretic either in infallibly defining a matter of faith and morals for the universal Church or as a private teacher, Bellarmine considers four theories on how a heretical pope (papa haereticus) could lose his office. First, he rejects the view held by Torquemada that a pope who is a secret heretic loses ipso facto membership in the Church (Bellarmine 1613: 3.2.30, vol. 1, 691). Bellarmine does not think that secret heresy is sufficient for a pope to lose his office. Second, he rejects the view that a heretical pope cannot be judged for manifest heresy. He considers this position as contrary to Si Papa and the practice of the Church, which had in fact condemned allegedly heretical popes such as Honorius (Bellarmine 1613: 3.2.30, vol. 1, 691). Third, Bellarmine also rejects Cajetan's view that a pope who is a manifest heretic is not ipso facto deposed by God but should be deposed by the Church. Trying to avoid conciliarism, Cajetan argued that when a council judges a heretical pope, it is not exercising authority over the pope as such but only over the conjunction of the papacy with a particular pope. Bellarmine rejects Cajetan's argument since he thinks that such a distinction still entails that a council is judging the pope. 
Bellarmine then turns to what he describes as the 'true' and 'common' opinion in the Church:

A Pope who is a manifest heretic, ceases per se to be Pope and head, just as he ceases per se to be a Christian and member of the body of the Church: therefore, he can be judged and punished by the Church (Bellarmine 1613: 3.2.30, vol. 1, 694).

In Bellarmine's view the Scriptures teach that faith is a necessary condition for one to be a member of the Church. Heresy is by definition the rejection of faith, and therefore a formal heretic loses membership in the Church (Hardon 2009). Paul in 1 Timothy 1:19 teaches that the heretic, through his heresy, is broken from the ship which is the Church, after which he sinks into the sea (Bellarmine 1613: 4.3.4, vol. 2, col. 110). The ipso facto loss of the papal office through formal heresy entails for Bellarmine that whoever renders a judgment of a heretical pope is not in fact judging the pope at all; he is merely judging a heretic.

Bellarmine, however, does agree with conciliarists that both local and ecumenical councils are a means for dealing with such heretical popes. Bellarmine recognizes that this was lawfully done by the Church in the past, and he gives several examples, including Pope Marcellinus who, according to some accounts, was accused with the sin of apostacy by 300 bishops at the Council of Sinuessa (Townsend 1933: 165-174; Moynihan 1961: 3). While this story is part of the Symmachian forgeries, nevertheless Bellarmine's comment upon it reveals that he thought that a local council could deal with the problem of a heretical pope. Bellarmine writes,

Marcellinus was accused of an act of infidelity, in which case a council can examine the case of the Pontiff. If the council were to find that he was really an infidel, it can declare him outside the Church and condemn him (Bellarmine 1613: 4.2.19, vol. 2, 100).

Bellarmine explains that the bishops did condemn Marcellinus, but only after the pope had condemned himself and, in that act, abdicated the papacy. Bellarmine also thought that ecumenical councils could adjudicate papal heresy, citing Honorius' condemnation by the third council of Constantinople (Bellarmine 1613: 3.2.30, vol. 1, 691).

At first blush, it may seem odd and contradictory for Bellarmine to hold his view as probable and pious and yet to call this fourth view true and common. There are two important points to make about Bellarmine's position. First, Bellarmine is honest enough to recognize that his own view is not the 'common' opinion in the Church, as it was unknown before the sixteenth century. The fourth view, Bellarmine notes, was held by 'all the ancient fathers', Si Papa, and Pope Innocent III (Bellarmine 1613: 3.2.30, vol. 1, 691). 
Moreover, he notes that the common opinion is also held by 'learned men of our age', including John Driedo (1480-1535) and Melchior Cano, O.P. (15091560). Second, Bellarmine's 'probable and pious' opinion is not strictly contradictory to this true and common opinion. It is, after all, a doctrine of the Church that anyone, whether pope or layman, who falls into manifest and pertinacious heresy is no longer a member of the Church. The pope himself is not exempted from this divine law. One can simultaneously hold that a pope who is a manifest and pertinacious heretic is not a member of the Church and that God has and will providentially prevent such an occurrence. This is like holding that anyone, including the Blessed Virgin, who commits a mortal sin and dies unrepentant will descend immediately to hell after the particular judgment. God, however, gave Mary graces such that she never committed such a sin.

Some medieval canonists like Huguccio (d. 1210) and conciliarists like Zabarella and Almain argued that Si Papa should be read broadly rather than narrowly so that it includes not only the crime of heresy but also notorious immorality (Zabarella 1566: 697; Almain 1728: cap. 12; Moynihan 1961: 7576; Tierney 2010: 9, 59-61; Oakley 1965: 673-690). Huguccio in effect argued that if the pope were to commit a notorious immoral act like fornication, he would be teaching the faithful through his example. Bellarmine rejects such an argument. If the supreme pontiff lives an immoral life, he must be fraternally corrected; but the pope cannot be judged in the judicial sense by any man (Bellarmine 1613: 3.2.27, vol. 1, 681; 3.3.21, vol. 1, 766). On this point Bellarmine argues that the tradition is clear that the only exception to the Church not judging the supreme pontiff is heresy. Finally, Bellarmine considers the opinion held by a number of medieval canonists, such as Alanus Anglicus (fl.c. 1190-c. 1210), that a pope can voluntarily subject himself to a council (Fraher 1976: 47-54). Bellarmine holds that 'the supreme pontiff cannot entrust to either a council or anyone else compulsory judgment over himself but only advisory judgments' (Bellarmine 1613: 4.2.18, vol. 2, col. 99). After all, as Bellarmine notes, the supreme power of the pope is of divine right, and not even the pope himself can dispense with a divine law. So, the pope is not even free to subject himself to the coercive power of the Church or council without violating divine law. The pope can only be judged by God (Bellarmine 1613: 4.2.18, vol. 2, col. 100). Moreover, if the pope were to coercively subject himself to another, it would follow that he would be both a superior and an inferior at the same time and in the same respect, which is inherently contradictory.

While Bellarmine repeatedly denies that a pope can be judged for anything other than heresy, he does think that it is lawful to resist a wicked or immoral pope in some cases. Conciliarists had argued that just as one may justly kill a pope who unjustly invades a territory, so it is all the more lawful 
for a king or a council to depose a pope who is attempting to destroy souls. Bellarmine's response to this argument follows that of Torquemada and Cajetan whom he approvingly cites (Cajetan 1936: cap. 27, pp. 178-179; Torquemada 1561 : lib. 2, cap. 106, p. $\left.246^{\mathrm{r}}-248^{\mathrm{r}}\right)$. He only denies the consequent; it would appear then that he admits that it is lawful for anyone to resist or even kill a pope who unjustly attacks him. Presumably, Bellarmine would also hold with Cajetan that while it is permissible to kill a pope in self-defense, it is not permissible to punish a pope for homicide with the death penalty (Cajetan 1936: cap. 27, p. 179). The reason for this is that the death penalty can only be applied if a person is judged guilty of the crime of homicide. Since no human can judge the pope, he cannot be punished with the death penalty. It is also equally lawful for a state to defend itself or even kill a pope who is unjustly invading it. This latter scenario may strike one as improbable, but one should remember the sixteenth-century example of Pope Julius II (r. 1503-1513), known as the warrior pope, who personally and bravely supervised the siege of Mirandola (Shaw 1993: 270). In any case, for Bellarmine individuals and states have a natural right to self- defense. Bellarmine also thinks that it is lawful to resist a pope who is attempting to destroy souls or the Church. While one cannot judge (in a juridical sense) the pope, one may resist him by refusing to do what he commands and by attempting to impede his unlawful commands (Bellarmine 1613: 3.2.29, vol. 1, col. 690). Bellarmine does not explain what he has in mind by 'destroying the Church'. Given his reference to Cajetan's De comparatione auctoritatis papae et concilii, however, it is probable that he holds a similar position to Cajetan, who gives several examples of what constitutes the pope destroying the Church, such as simony on the pope's part or the conferral of benefices for money (Cajetan 1936: cap. 27, p. 179).

Gerson had argued, at least as Bellarmine reports, that the Church has to be able to depose a corrupt pope so that it can heal itself. If the Church cannot depose a corrupt pope, then it is not even as competent as a state that can depose a corrupt ruler who is attempting to destroy it. Bellarmine responds that the Church is not principally dependent on human works for its protection but on God. God in His providence will always protect His Church. Bellarmine held that God would sometimes directly intervene. Later in Bellarmine's career, this theory was put to the test. During the de auxilliis controversy, Pope Clement VIII (r. 1592-1605) informed Bellarmine that he was going to define in favor of the Dominican position against the Jesuit position in the matter of grace. Bellarmine told Pope Clement that he would do no such thing and predicted to Cardinal Del Monte that the pope would die if he attempted to do such a thing. Clement VIII died not long after, no doubt confirming in Bellarmine's mind his own theory (Bellarmine 1999: 78; Brodrick 1928: 2:56, 111). Bellarmine's trust in God's direct intervention to 
protect His Church does not mean that there is nothing that Christians or the Church can or should do in such a case. After all, God often accomplishes His will through secondary causes, such as sacraments or men. In the case of a pope attempting to destroy the Church, Bellarmine gives several examples of what the Church or Christians can do. First, they can pray for the conversion of the pope or his removal from office. Second, they can also admonish him or correct him with humility and reverence. Lastly and strikingly, Bellarmine argues that one may even use military force to stop a pope from destroying the Church (Bellarmine 1613: 4.2.19, vol. 2, col. 103).

\section{Conclusion}

Bellarmine does not advocate for an absolute papal monarchy in which there are no 'constitutional' limitations on the papacy. Christ alone is the absolute king of the Church; the pope is merely the His steward. Moreover, only Christ has a true fullness of power; the pope has a fullness only relative to that of the bishops. Nevertheless, Christ immediately instituted the pope as the supreme head of the Church on earth, and as such, the pope has supreme ecclesiastical power over the whole Church on earth. This supreme authority has limits that are part of the nature of Christ's Church. For Bellarmine, God's Word, as found in Sacred Scripture and Apostolic Tradition, has supreme authority in the Church. Bellarmine's point, to use the words of the Second Vatican Council, is that a pope must 'serve' revelation by 'teaching only what has been handed on' (Dei verbum 10). A pope may not issue new public revelation for he is not like the oracle at Delphi or the President of the Mormon Church, who can issue new revelation or invalidate either natural or supernatural revelation. Bellarmine's point, to use the words of the First Vatican Council, is that 'the Holy Spirit was not promised to the successors of Peter that they might disclose a new doctrine by his revelation' (DH 3070). If a pope to attempt to issue new revelations or to contradict God's Word, he would simply lose his office and a new pope would have to elected. While Bellarmine rejects as contrary to Church teaching the conciliarist argument that a council can judge (juridically) either a heretical or an immoral pope, he agrees with the conciliarists that a council is a way to deal with the problem of a heretical pope. Finally, if a pope were to attempt to destroy the Church, Bellarmine thinks that either God would directly intervene or, depending on the circumstances, one may have recourse to the use of military force to stop him from doing so.

\section{Bibliography}

Almain J (1728) Tractatus de auctoritate ecclesiae. In Joannis Gersonii doctoris theologici E cancellarii Parisiensis opera omnia, novo ordine digesta, E in V. tomos distributa; ad manuscriptos codices quamplurimos collata, E innumeris in locis 
emendata; quadam etiam nunc primùm edita: quibus accessêre Henrici de Hassia, Petri de Alliaco, Joannis Brevicoxe, Joannis de Varenis Scriptorum coctaneorum, ac insuper Jacobi Almä̈ni E Joannis Majoris Tractatus, partim editi partim inedita, 2nd edition. Hagæ Comitum: apud Petrum de Hondt.

Antoninus (1959) Summa theologica. Graz: Akademische Drucku. Verlagsanstalt.

Bäumer R (1967) Das Kirchenverständnis Albert Pigges. Ein Beitrag zur Ekklesiologie der vortridentinischen Kontroverstheologie. In Bäumer R and Dolch H (eds) Volk Gottes. Zum Kirchenverständnis der katholischen, evangelischen und anglikanischen Theologie. Festgabe für Josef Höfer. Freiburg: Herder.

Bellarmine R (1999) Autobiografia (1613): con Sinossi dei dati cronologici della Biografia di Bellarmino e delle sue pubblicazioni. Gustavo Galeota, S.J., and Pasquale Giustiniani (eds) Brescia: Morcelliana.

Bellarmine R (n.d.) Compendium de haeresi. Trier: Stadtbibliothek, Ms. $792 / 1373$.

Bellarmine R (1613) Disputationes Roberti Bellarmini Politiani Societatis Jesu, de controversiis Christianae fidei, adversus hujus temporis haereticos. Paris: Triadelphorum.

Bellarmine R (1931-32) Explanatio in Psalmos. Galdos R (ed) Rome: Pontificiae Universitatis Gregorianae.

Bellarmine R (1576-77) In 3. Partem Summae S. Thomae de Aquino, Louvain. Bibliothèque Royale Albert $\mathrm{I}^{\mathrm{er}}, \mathrm{KBR} 4243$, fols. $1^{\mathrm{r}}-260^{\mathrm{v}}$. Also found in Commentaria in Summa Theologiae D. Thomae. Copia transciptionis facta a R.P.S. Tromp, S.I. A typewritten copy at the Archives of the Gregorian Pontifical University: APUG, Fondo Tromp, nn. 2419-2430.

Bellarmine R (1606) Riposta a dve libretti, vno de quali s'intitola, Risposta di vn dottore di theologia [i.e. G. Marsilio] ad vna lettera scrittagli da vn reuerendo suo amico, sopra il breue di censure dalla santità di Paolo V. publicate cotro li sig. Venetiani. Et l'altro, Trattato E resolutione sopra la validità delle Guglielmo Facciotto. Roma: S. Paolini.

Brodrick J (1928) The Life and Work of Blessed Robert Francis Cardinal Bellarmine. London: Burns, Oates, and Washbourne.

Cajetan (1936) De comparatione auctoritatis papae et concilii. Cum apologia eiusdem tractatus. Pollet VMJ (ed) Rome: Angelicum.

Congar Y (1974) Saint Thomas Aquinas and the Infallibility of the Papal Magisterium (Summa Theologiae, II-II, q. 1, a. 10). The Thomist: A Speculative Quarterly Review 38: 90.

Costigan R (2005) The Consensus of the Church and Papal Infallibility: A Study in the Background of Vatican I. Washington, DC: The Catholic University of America Press.

De Palude P (1966) Tractatus de potestate papae. Stella PT (ed) Zürich: PasVerlag. 
Peri V (1963) Il numero dei concili ecumenici nella tradizione cattolica moderna. Aevum 37: 430-501.

De Torquemada J (1496) Summa de ecclesia contra impugnatores potestatis summi pontificis et LXXIII quaestiones super potestate et auctoritate Papali ex sententiis sancti Thomae Aquinatis. Lyons: Per Magistrus Johannem Trechsel.

De Torquemada J (1561) Summa de ecclesia contra impugnatores potestatis summi pontificis et LXXIII quaestiones super potestate et auctoritate Papali ex sententiis sancti Thomae Aquinatis. Venetiis: Apud Michaelem Tramezinum.

Dietrich T (1999) Die Theologie der Kirche bei Robert Bellarmin (1542-1621). Paderborn: Bonifatius.

Deferrari J (1960) Dictionary of St. Thomas Aquinas. Boston: St. Paul Editions.

Fraher RM (1976) Alanus Anglicus and the Summa Induent Sancti. Bulletin of Medieval Canon Law 6: 47-54.

Friedberg A (1955) Corpus iuris canonici. Graz: Akademische Druck-u. Verlagsanstalt.

Gerson J (1966) De potestate ecclesiastica et de origine juris et legum. In Loeuvre ecclésiologique $(253 a-291)$. Paris: Desclée.

Hardon JA (2009) A Comparative Study of Bellarmine's Doctrine on the Relation of Sincere Non-Catholics to the Catholic Church. Bardstown, KY: Eternal Life.

Horst U (1978) Papst, Konzil, Unfehlbarkeit: d. Ekklesiologie d. Summenkommentare von Cajetan bis Billuart. Mainz: Matthias-Grünewald-Verlag.

Hünermann P, Hoping H, Fastiggi RL, Englund Nash A, and Denzinger H (eds) (2012) Compendium of Creeds, Definitions, and Declarations on Matters of Faith and Morals, 43rd edition. San Francisco: Ignatius Press.

Iserloh E (1983) Luther and the Council of Trent. The Catholic Historical Review 69: 463-476.

Jacobazzi D (1903) De Concilio tractatus. In Sacrosancta concilia ad Regiam editionem exacta: quae nunc quarta parte prodit auctior. Paris: Impensis Societatis Typographicae Librorum Ecclesiasticorum jussu Regis constitutae.

Jedin H (1957-61) A History of the Council of Trent. Graf E (trans) London: Thomas Nelson and Sons.

Jedin H (1931) Studien über die schriftstellertätigkeit Albert Pigges. Münster in Westfalen: Aschendorff.

Klaiber W (comp.) (1978) Katholische Kontroverstheologen und Reformer des 16. Jahrhunderts. Münster in Westfalen: Aschendorff.

Le Bachelet XM (1911) Bellarmin avant son Cardinalat, 1542-1598: Correspondance et documents. Paris: Gabriel Beauchesne et Compagnie.

Leo X (1991) Exsurge Domine. In Dokumente zur Causa Lutheri (1517-1521). Fabisch $\mathrm{P}$ and Iserloh E (eds) Münster: Aschendorffsche Verlagsbuchhandlung.

Löhr T (1982) Die Lehre Robert Bellarmins vom allgemeinen Konzil. STD Thesis, Pontifical Gregorian University, Italy. 
Löhr T (1986) Die Lehre Robert Bellarmins von allgemeinen Konzil. Excerpta ex dissertatione in Pont. Univ. Gregoriana Limburg.

Manelis F (1940) De regia Christi potestate ad mentem sancti Roberti Bellarmini. PhD Thesis, Pont. Univ. Gregoriana, Vilkaviskis 'Olimpija'.

Mansi GD, Coleti N, Cossart G, and Labbe P (1972) Sacrorum conciliorum nova, et amplissima collectio: in qua preter ea que Phil. Labbeus, et Gabr. Cossartius S.J. et novissime Nicolaus Coleti in lucem edidere ea omnia insuper suis in locis optime disposita exhibentur, qua Johannes Dominicus Mansi ... evulgavit. Florence: Expensis Antonii Zatta Veneti.

Merzbacher F (1967) Die Kirchen und Staatsgewalt bei Jacques Almain. In Lentze H and Ganipl I (eds) Speculum Juris et Ecclesiarum: Festschrift für Willibald M. Plöchl zum 60. Vienna: Herder.

Morerod C (2019) Tommaso De Vio (Cajetan) et la bulle Pastor Aeternus sur le primat du Pape. In Minnich N (ed) Alla ricerca di soluzioni, nuova luce sul Concilio Lateranense V: studi per i 500 anni del Concilio. Città del Vaticano: Libreria editrice vaticana.

Moynihan JM (1961) Papal Immunity and Liability in the Writings of the Medieval Canonists. Gregorian Biblical BookShop.

Natalis H (1966) De potestate papae. In In quatuor libros Sententiarum commentaria. Quibus adiectus est eiusdem auctoris tractatus De postestate Papae. Farnborough: Gregg.

Oakley F (1965) Almain and Major: Conciliar Theory on the Eve of the Reformation. The American Historical Review 70: 673-690.

Oakley F (1999) Bronze Age Conciliarism: Edmond Richer's Encounters with Cajetan and Bellarmine. History of Political Thought 20: 65-86.

Oakley F (1996) Complexities of Context: Gerson, Bellarmine, Sarpi, Richer and the Venetian Interdict of 1606-1607. Catholic Historical Review 82: 128.

Oakley F (1972) Conciliarism at the Fifth Lateran Council? Church History 41: 452-463.

Oakley F (2003) The Conciliarist Tradition: Constitutionalism in the Catholic Church 1300-1870. Oxford: Oxford University Press.

Posthumus Meyjes G (1999) Jean Gerson, Apostle of Unity: His Church Politics and Ecclesiology. Leiden: Brill.

Richardt A (2004) Saint-Robert Bellarmin, 1542-1621: le défenseur de la foi. Paris: F.-X. de Guibert.

Richgels RW (1980) The Pattern of Controversy in a Counter-Reformation Classic: The Controversies of Robert Bellarmine. The Sixteenth-Century Journal 11: 3-15.

Ryan EA (1936) The Historical Scholarship of Saint Bellarmine. New York: Fordham University Press.

Shaw C (1993) Julius II, the Warrior Pope. Oxford: Blackwell. 
Sieben HJ (1988) Konzilien in der Sicht des Kontroverstheologen Bellarmin. In Die katholische Konzilsidee von der Reformation bis zur Aufklärung. Paderborn: F. Schöningh.

Sieben HJ (1986) Robert Bellarmin und die Zahl der Ökumenischen Konzilien. Theologie und Philosophie 61: 24-59.

Silvestri F (1552) D. Thomae Aqvinatis ex Praedicatoria Familia, Svmma contra gentiles: quatvor libris comprehensa: Commentariis. Parisiis: Apud Viuantium Gaultherotium.

Tanner N (ed) (1990) Decrees of the Ecumenical Councils. London: Sheed and Ward; Washington, D. C.: Georgetown University Press.

Terreni G (1926) Quaestio de magisterio infallibili romani pontificis. Xiberta y Roqueta BM (ed) Monasterii: typis Aschendorff.

Tierney B (2010) Foundations of the Conciliar Theory: The Contribution of the Medieval Canonists from Gratian to the Great Schism. Cambridge: Cambridge University Press.

Tierney B (1988) Origins of Papal Infallibility, 1150-1350: A Study on the Concepts of Infallibility, Sovereignty and Tradition in the Middle Ages. Leiden: E. J. Brill.

Torres F (1551) De summi pontificis: supra concilia auctoritate ad reverendiss. dominum Ioannem Salviatum episcopum cardinalem, libri tres. Eiusdem de residentia pastorum iure divino scripto sancita ad eundem liber. Eiusdem de actis veris sexte synodi, deque canonibus, qui eiusdem sexta synodi falso esse feruntur, E de septima synodo atque multiplici octava ad eundem liber. Florentiae: [Laur. Torrentinum].

Townsend WT (1933) The So-Called Symmachian Forgeries. The Journal of Religion 13: 165-174.

Tromp S (1935) Conspectus Chronologicus Praelectionum, quas habuit S. Robertus Bellarminus in Collegio S. I. Lovaniensi et Collegio Romano. Gregorianum 16: 97-105.

Tromp S (1934) De Bellarmini indice haereticorum Treviris reperto. Gregorianum 15: 187-214.

Tromp S (1933) De facultate S. Rob. Bellarmini legendi libros prohibitos. Archivum Historicum Societatis Iesu 2: 326-328.

Van Leeuwen D (1533) D. Dionysii Carthvsiani contra Alchoranum et sectam Machometicam libri quinque. Köln: Apud Petrum Quentel.

Washburn CD (2010) St. Robert Bellarmine on the Infallibility of General Councils of the Church. Annuarium Historiae Conciliorum 42(1): 171-192.

Washburn CD (2019A) The Councils of Trent and Vatican I. In The Oxford Handbook of Catholic Theology. Oxford: Oxford University Press.

Washburn CD (2019B) Three 16th Century Thomist Solutions to the Problem of a Heretical Pope: Cajetan, Cano, and Bellarmine. The Thomist: A Speculative Quarterly Review 83: 547-588. 